\title{
Effects of Jigsaw Strategy into Flipped Learning on EFL Pre-serviced Kindergarten Teachers' English Attitude and Motivation with Online-Based Classroom
}

\author{
Hyelin Jeong
}

\begin{abstract}
This research applied a jigsaw strategy in flipped learning to improve English attitude and motivation of EFL pre-kindergarten teachers. For this purpose, online-based flipped learning was planned and executed by dividing 48 pre-serviced kindergarten teachers into an experimental group $(n=25)$ and a control group $(n=23)$. In particular, the jigsaw strategy was applied by differentiating the discussion method between the experimental group and the control group, and various topics for 'English in Early Childhood' lecture were provided for about 10 weeks. As a result, the English attitude and motivation post-scores of the experimental group were improved, and there were significant differences between the experimental group and the control group. Accordingly, this research verified the effectiveness of the teaching method to encourage learners' participation in the distance learning environments caused by COVID-19 pandemic. At the same time, this research also significant in that it has prepared new alternatives to EFL English learners that rely on the face-to-face educational methods.
\end{abstract}

Index Terms-Jigsaw strategy, flipped learning, EFL, pre-serviced kindergarten teacher, English attitude and motivation.

\section{INTRODUCTION}

With the advent of the 4th industrial revolution, a movement of automation is taking place to smoothly improve the connections between various objects such as people and people, people and nature, and people and robots. In this trend, education for human-beings places importance on international and real-time communication capabilities so that it can analyze and process a lot of information and big data. Accordingly, education make the learners think creatively and study self-directed.

In the COVID-19 pandemic, these changes in educational environments were accelerated and promoted faster than expected. Classes that were conducted in the conventional face-to-face educational methods are conducted in the un-tact educational methods to protect against infection by COVID-19. A way to interact with each other through online was sought, and cloud-based peer-to-peer software platforms such as Zoom platform and Webinar were used.

Accordingly, the composition of learners' knowledge has been transformed so that it can be created anytime, anywhere, free from the constraints of the physical environment inside and outside the classroom.

Manuscript received March 12, 2021; revised June 11, 2021

H. Jeong is with the Department of Global Child Education, Woosong University, Daejeon, South Korea (e-mail: jyang0821@wsu.ac.kr).
Changes in the physical classroom environment had a significant impact on the way the learners and instructors communicate knowledge. Traditional teaching methods used in classrooms have been in the form of direct transfer of knowledge by instructors for a fixed amount of time, but the new educational model has encouraged the process-oriented methods to create diverse experiences for learners. For example, methods such as MOOC, competency-based learning, and Coding Bootcamp, which are conducted online in university education, support learners and instructors to evaluate and cooperate with each other's learning models in an online context.

The digitalization of these teaching methods provides a new alternative to educational technology. The flipped learning digitally reinterpreted Bloom's taxonomy. Bloom's taxonomy emphasizes that education can gradually develop from a lower level to a higher mental capacity through the sex-steps processes called knowledge - comprehension application - synthesis - evaluation. The 'knowledge' and 'comprehension' are steps to gain recognizing facts and understandings, 'application' is a step to apply the knowledge to solve the problem, 'analysis' is step to analyze concepts and relationships to derive inference, 'synthesis' is a step to synthesize knowledge and concepts in new ways, 'evaluation' is a step to evaluate opinions and objectives. Especially, in classroom, it is limited to the steps of knowledge and comprehension, and outside the classroom, the role has to be performed from application to evaluation. On the other hand, the flipped learning proposes the completely inverted teaching methods. It requires learners to perform the steps of knowledge and comprehension outside the classroom and then participate the higher steps from application to evaluation in the classroom.

The inverted learning methods are conducted through the blended learning of online and offline classes. In other words, it is organized to carry out tasks or discussions that the learner wanted to participate in outside the classroom. Previous researchers classified the activities studying outside or inside the classroom as follows. Crouch and Mazur [1] categorized the activities as the forms in which students read all the materials about the subjects before coming to the classroom and then participate in their discussions or tasks in the classroom. Similarly, Andersond and Walvoord [2] suggested that students learn the contents of learning through writing or problem solving before class participation, so that they can receive feedbacks from instructors mainly focusing on analysis or synthesis in the classroom.

The higher the participation of learners in flipped learning, the greater the proportion of discussion or debate activities as 
part of cooperative learning to promote interactions with each other. However, there are some limitations in the traditional debate and discussion activities. However, there are some limitations in the traditional debate and discussion activities. The learners' participation may not be the same, and if they may not maintain interests, the quality of their outputs may be lower than that of activities individually. In addition, if the instructor may not assist learners who have not participate classroom activities, it may lead to a lack of modeling or guidance, and thus the learners may not be improved.

On the other hand, flipped learning-based discussion or debate activities can be used by learners as a means of collaborative problem solving or interaction within educational subjects [3]. For example, the discussion questions in learner's online lecture video are included in advance to check whether to learn beforehand. At the same time, if the learners use the LMS to post their discussion board in online classroom, they can easily check the feedbacks of peer learners while viewing the comments on the question. However, even in these cases, discussion or debate activities may not continue if free riders occur during studying without proper help from professors.

As an alternative to these limitations, the Jigsaw strategy assigns learners on the role of an expert about the subject contents so that they can play their roles to treat the discussions or debate activities. The group of Jigsaw strategy provides an opportunity for 5-6 members to discuss through cooperative learning. This gives intergroup members a shared learning, similar to matching jigsaw puzzles, so that they can consist of one piece of knowledge as a whole.

In order to conduct jigsaw cooperative learning, the original group is formed first and worksheets are distributed to experts who belong to each of the original groups. Therefore, experts form a separate group to conduct another cooperative activities. After cooperative learning is over, return to the original group to proceed with cooperative learning and review the learning contents individually. Previous studies reported that when flipped learning and Jigsaw strategy were applied together, learners' motivation, class participation, and class satisfaction were high, and academic achievement, learning satisfaction, communication skills, problem solving skills, and self-directed learning skills improved [4].

Flipped learning using the Jigsaw strategy can have the positive effects on pre-kindergarten teachers' English education in EFL situations. In flipped learning-based language learning conducted by Hwang, Chen, Sung, \& Lin [5], learners improved their reading comprehension, and accordingly, intrinsic and extrinsic motivation for learning showed a positive correlation. This helps learners to solve the dilemma of individual knowledge composition. It also has the advantage of promoting weaker speaking in EFL situations by enhancing interaction among learners. In addition, Wu, Hsieh, and Yang [6] also reported that the learning motivation was improved as a result of oral training to EFL learners based on flipped learning. Taken together, it can be seen as if the learners are trained by flipped learning in English study, they can participate in self-directed participation, and it is effective not only for their language ability but also motivation.
South Korea is an EFL (English as a Foreign Language) environment in which English is used as a foreign language, and English education is conducted through public education during elementary school period. Accordingly, English education is mainly conducted through private education during the early childhood period, but according to the trends of the multicultural society, English is also being taught at childcare institutions used by infants and young children. Pre-kindergarten teachers also demand communication capabilities related to English, so efforts are urgently needed to reform the curriculums in Korean universities that train teachers.

Therefore, this study attempts to apply a direct discussion approach in a flipped learning situation to improve the ability of pre-kindergarten teachers to use English. To this end, the Jigsaw strategy is applied in a flipped learning method for 10 weeks to verify whether learners' attitudes and motivations toward English use are effective. The question in this research was organized as follows.

Does flipped learning with Jigsaw strategy affect pre-serviced kindergarten teachers' English Attitude and motivation in EFL contexts?

\section{RESEARCH DESIGN}

The following study was designed to confirm whether the attitude and motivation for EFL pre-serviced kindergarten teachers' English changed when the jigsaw strategy was blended by flipped learning in the online-based classroom.

\section{A. Participants}

In order to check the effects of the jigsaw strategy in the online-based classroom, the experimental group and control group were sampled as follows.

48 junior college students $($ Male $=4$, Female $=44$, Mean of Age $=19.40$, and $\mathrm{Sd}=1.33$ ) were selected to participants from the same prior backgrounds. They were all Korean EFL learners and taught by the same professor and had no experience in flipped learning.

25 students out of 48 participants were assigned to the experimental group, while 23 students were allotted to the control group. Both groups were taught using flipped learning in the online-based classroom, but the Jigsaw strategy was only implemented in the experimental group. Fig. 1 summarizes the variables to be checked in this research.

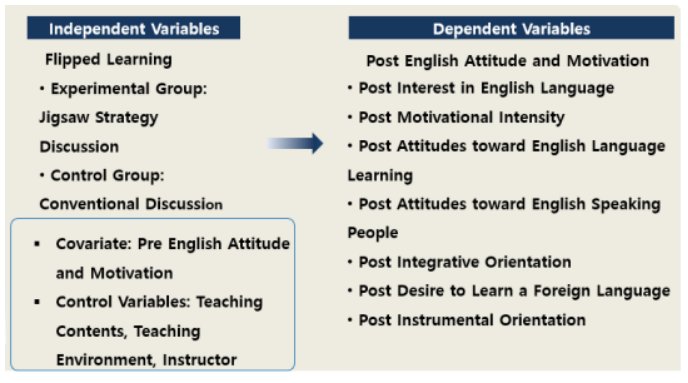

Fig. 1. Variables and instruments involved in the research.

\section{B. Instructional Activities for Flipped Learning}

The instructional mini lecture was created and edited by 
one experienced professor using Microsoft Power Point Slide Recoding System. It was also produced by professors to allow students to write a Lecture Tutorial for mini-lecture at the same time. The professor produced the Lecture Tutorial and provided it to students every time so that they could record and organize their contents while taking mini lecture, and uploaded it to LMS. In addition, the professor recorded the video to be played for approximately 15 minutes at each time and sent it to learners via Zoom application.

Fig. 2 and 3 shows an example of a scene in which a mini lecture produced by an instructor is transmitted and an example of the lecture tutorial.

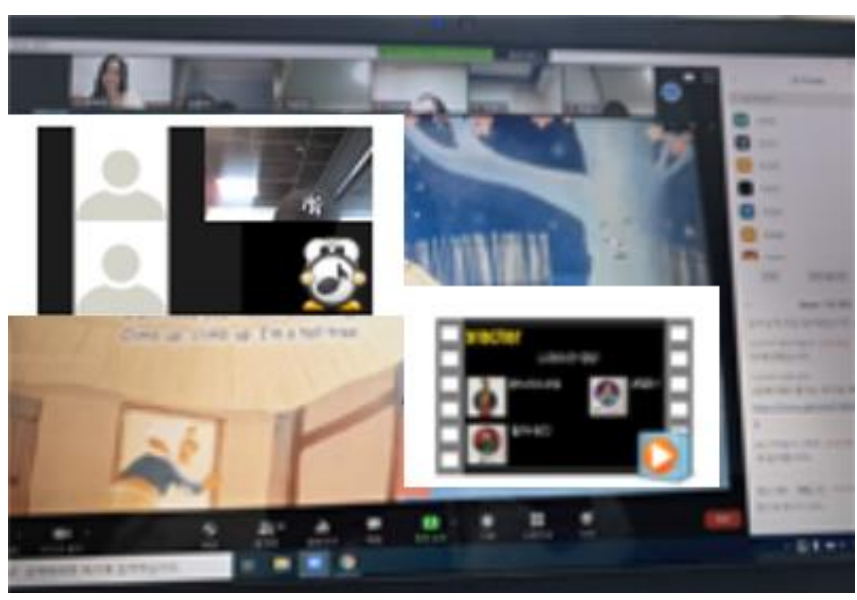

Fig. 2. Recorded mini lecture sample using Zoom.

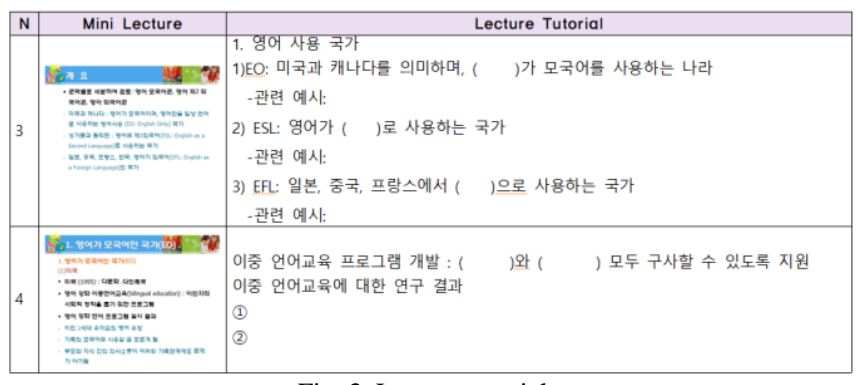

Fig. 3. Lecture tutorials.

\section{Jigsaw Strategy Discussion}

In this study, in order to apply jigsaw strategy activities in flipped learning situations, the following processes were sequentially conducted.

First of all, the group was divided into five to six members in relation to the contents of the lecture and a small group rooms were created using Zoom.

Next, feedback between expert group and jigsaw group was conducted to activate jigsaw strategy among students.

Finally, it was configured so that the professor can give overall feedback from the expert group. In particular, worksheets presented in Fig. 4 were required to record these feedbacks.

The Jigsaw strategy was carried out in the following sequence, and these types of discussion were conducted only in the experimental group.

Step 1. Check the topic of discussion: Check what the topic of discussion is related to the lecture content in the video material.

Step 2. Dividing the students into Jigsaw groups: Divide all students into 3-4 groups per group. At this time, experts are designated for each group, and these are changed according to the subject.

Step 3. Searching for a solution to the discussion topic: For each group, study solutions to solve the discussion topic.

Step 4. Forming expert group: An expert group is formed, and experts extracted from each group are gathered. The experts meet with agendas that could not be resolved in each group to explore further knowledge. At this time, the instructor also intervenes and gives feedback.

Step 5. Returning to their Jigsaw group: Experts go back to each Jigsaw group and look for solutions to unresolved topics. At this time, you can give relevant feedback to your team members.

Step 6. Presenting solutions for each group: Organize the contents of discussion assigned to each group, and present them with other students.

\begin{tabular}{|c|c|}
\hline 챈트 내용(가사) & 주의할 점 \\
\hline $\begin{array}{c}\text { Up, up, up the tree, } \\
\text { To the top, top, top, top, } \\
\text { top. } \\
\text { I'm there! }\end{array}$ & $\begin{array}{r}\text { To the top!, top!, top!, } \\
\text { (한 템포 쉬고) } \\
\text { top!, top! } \\
\text { I'm there!!!! }\end{array}$ \\
\hline $\begin{array}{r}\text { Down, down, down the } \\
\text { tree, }\end{array}$ & $\begin{array}{r}\text { D(!)won!, d(!)own, d(!)own } \\
\text { the tree , (한 템포 쉬고) }\end{array}$ \\
\hline $\begin{array}{c}\text { To the bottom, bottom, } \\
\text { bottom, bottom, bottom. }\end{array}$ & $\begin{array}{r}\text { Tott(!)om!, } \\
\text { bott(!)om!, bott(!)om!, } \\
\text { bott(!)om!, bott(!)om. } \\
\text { I'm there!!!! }\end{array}$ \\
\hline
\end{tabular}

Fig. 4. Jigsaw strategy worksheets for the experimental group.

\section{Experimental Procedure}

This research was conducted over a period of 10 weeks in the Zoom online classrooms. The experimental group and control group conducted a lecture on 'English in Early Childhood' as shown in Table I using flipped learning. Before the lecture, a pre-test on English attitude and motivation of the experimental group and control group was conducted in August 2020, and a post-test was conducted in December 2020 using the same scale. This resulted in the extraction of pre-scores and post-scores of each group.

The experimental group and control group studied the English lectures through pre/in/post classes as shown in Fig. 5 .

First, during the pre-class, the students watched the mini lecture filmed in advance by their professor, and completed the lecture tutorial. This process provided an opportunity to study the subject to be studied in advance.

Next, discussion was conducted during the in class, but jigsaw strategy was applied to the experimental group only. Worksheets were provided to record expert activities conducted within the expert group only. After the expert activities were over, they returned to the Jigsaw group and provided feedback on the content.

Finally, to organize the lecture, quiz was processed using the online Google Form. In addition, individual summary of 
the lecture was also prepared.

TABLE I: LECTURE PROGRAM FOR 10 WEEKS

\begin{tabular}{|c|c|c|}
\hline Wee & Lecture title & Lecture programs \\
\hline 1 & $\begin{array}{l}\text { Pre-test } \\
\text { and Orientation }\end{array}$ & $\begin{array}{l}\text { Introduction of the lecture and } \\
\text { pre-test } \\
\text { on English attitude and } \\
\text { motivation }\end{array}$ \\
\hline 2 & $\begin{array}{l}\text { Theory of English } \\
\text { Education }\end{array}$ & $\begin{array}{l}\text { The necessity and purpose of } \\
\text { English } \\
\text { education in early childhood }\end{array}$ \\
\hline 3 & $\begin{array}{l}\text { Teaching } \\
\text { Activities }\end{array}$ & 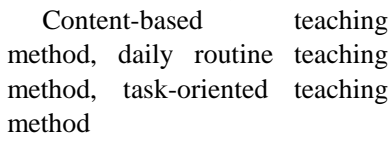 \\
\hline 4 & English Chants & $\begin{array}{l}\text { Benefits and effects of English } \\
\text { chants }\end{array}$ \\
\hline 5 & $\begin{array}{l}\text { English Chants for } \\
\text { early childhood }\end{array}$ & $\begin{array}{l}\text { Types of chants and how to use } \\
\text { them in early childhood }\end{array}$ \\
\hline 6 & English Song & $\begin{array}{l}\text { Benefits and effects of English } \\
\text { song }\end{array}$ \\
\hline 7 & $\begin{array}{l}\text { English songs for } \\
\text { early childhood }\end{array}$ & $\begin{array}{l}\text { Types of songs and How to } \\
\text { Use them in early childhood }\end{array}$ \\
\hline 8 & Dramatic play & $\begin{array}{l}\text { Benefits and effects of English } \\
\text { dramatic play }\end{array}$ \\
\hline 9 & $\begin{array}{l}\text { Let's play the } \\
\text { musical }\end{array}$ & Musical playing by group \\
\hline 10 & Post-test & $\begin{array}{l}\text { Post-test on English attitude } \\
\text { and } \\
\text { motivation }\end{array}$ \\
\hline
\end{tabular}

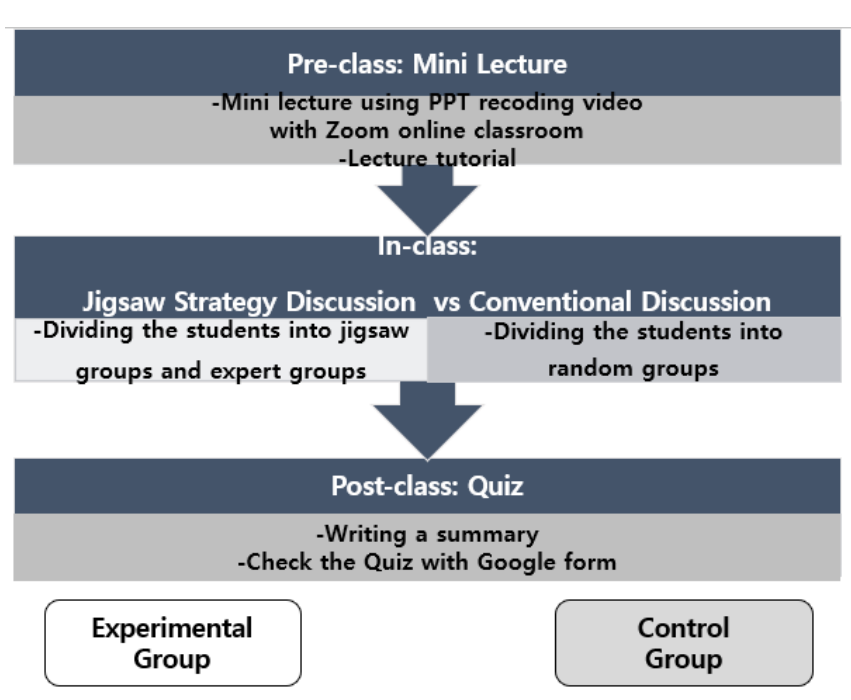

Fig. 5. Experimental procedure on the research.

\section{ANALYSIS}

\section{A. Instruments}

The Attitude/Motivation Test Battery was designed by Gadner and Smythe [7] to test attitude, motivation in learning English language. The reason for using this scale is that it is designed to be applicable to learners who have chosen English as their second language in EFL contexts. Accordingly, it was expected that it could be applied to Korean pre-school teachers.

The scale was composed of 12 subscales, but to verify the positive effect on English proficiency, only 7 areas were selected and measured, excluding the area for English anxiety. All of items were measured on a 6-point Likert scale, and classified from 'strongly disagree' to 'strongly agree'. The higher the score in each subscale, the more positive attitude and motivation for English is formed. There were items that required reverse coding for this scale, and were measured by reflecting them as shown in Table II. As a result of measuring the reliability of the subscale, it was evaluated as good.

TABLE II: ATTITUDE AND MOTIVATION TEST BATTERy ITEMS AND CRONBACH'S ALPHA ON EACH SUBSCALE

\begin{tabular}{|c|c|c|}
\hline Subscales & Items on Subscale & $\begin{array}{l}\text { Cronbach's } \\
\text { Alpha }\end{array}$ \\
\hline $\begin{array}{l}\text { Interest in } \\
\text { English }\end{array}$ & $\begin{array}{l}1,9^{*}, 16,24^{*}, 32, \\
41^{*}, 48,56^{*}, 63,70^{*}\end{array}$ & .82 \\
\hline $\begin{array}{l}\text { Motivational } \\
\text { Intensity } \\
\text { Attitudes }\end{array}$ & $\begin{array}{l}2^{*}, 10,17^{*}, 25,33^{*}, \\
42,49^{*}, 57,64^{*}, 71\end{array}$ & .57 \\
\hline $\begin{array}{l}\text { toward } \\
\text { English } \\
\text { learning }\end{array}$ & $\begin{array}{l}4,14^{*}, 19,29^{*}, 35, \\
46^{*}, 51,61^{*}, 66,74^{*}\end{array}$ & .88 \\
\hline $\begin{array}{l}\text { Attitudes } \\
\text { toward } \\
\text { English } \\
\text { speaking } \\
\text { people }\end{array}$ & $\begin{array}{l}5,20,31,36,39,52, \\
67,76\end{array}$ & .84 \\
\hline $\begin{array}{l}\text { Integrative } \\
\text { orientation }\end{array}$ & $6,21,37,53$ & .80 \\
\hline $\begin{array}{c}\text { Desire to } \\
\text { learn English }\end{array}$ & $\begin{array}{l}7,13^{*}, 22,28^{*}, 38, \\
45^{*}, 54,60^{*}, 68,73^{*}\end{array}$ & .86 \\
\hline $\begin{array}{l}\text { Instrumental } \\
\text { orientation }\end{array}$ & $11,26,43,58$ & .77 \\
\hline
\end{tabular}

\section{B. Data Analysis}

The collected data through the questionnaires were codified and entered into SPSS 20.0 to test the research question.

First, the mean and standard deviation were calculated to know the demographic information of the survey participants, and Cronbach's alpha was extracted to determine the reliability of the scale. In addition, t-test was conducted to verify the homogeneous between pre-test and post-test scores, and ANCOVA was conducted to compare their scores between the experimental and control groups.

\section{RESUlTS}

\section{A. Pre-test scores of English Attitude and Motivation between Experimental and Control Groups}

Table III shows the results of the homogeneous verification by checking whether there are the differences in prior scores between the experimental and control groups. As a result, there was no significant difference between English attitude and motivation. Although there was no significant difference between groups, when comparing the average scores for each subscale, the experimental group had lower scores for English attitude and motivation in all areas except for the instrumental orientation area compared to the control group.

\section{B. Post-test Scores of English Attitude and Motivation between Experimental and Control Groups}

To examine whether there is a significant difference in English attitude and motivation of the experimental group and control group, ANCOVA was conducted with pre-scores as the covariates and post-scores as the dependent variables in each subscale. As shown in Table IV, except for the 
integrative orientation area, the experimental group had significant differences between the control groups.

There were significant differences in 6 subscales, such as interest in English $(F=11.98, p<.01)$, motivational Intensity $(F=143.56, \quad p<.001)$, attitudes toward English $(F=26.60$, $p<.001)$, Attitudes toward English speaking people ( $F=10.84$, $p<.05)$, Desire to learn English $(F=4.84, p<.05)$, Instrumental orientation $(F=11.27, \quad p<.05)$. In these areas, the experimental group had higher average post-scores than those of the control group.

TABLE III: T-Tests OF PRE ATtITUdE AND MOTIVATION SCORES BETWEEN TwO GROUPS

\begin{tabular}{|c|c|c|c|c|c|c|}
\hline Variables & Groups & $N$ & Mean & $S D$ & $t$ & $p$ \\
\hline \multirow[t]{2}{*}{ Interest in English } & Experimental & 25 & 40.68 & 7.98 & -.36 & .72 \\
\hline & Control & 23 & 41.43 & 6.27 & & \\
\hline Motivational Intensity & Experimental & 25 & 37.64 & 5.44 & -.64 & .53 \\
\hline \multirow[t]{2}{*}{ Attitudes toward English learning } & Experimental & 25 & 37.96 & 9.53 & -.38 & .70 \\
\hline & Control & 23 & 38.87 & 6.53 & & \\
\hline \multirow[t]{2}{*}{ Attitudes toward English speaking people } & Experimental & 25 & 32.00 & 6.83 & -.68 & .50 \\
\hline & Control & 23 & 33.22 & 5.35 & & \\
\hline \multirow[t]{2}{*}{ Integrative orientation } & Experimental & 25 & 18.72 & 3.82 & -.25 & .80 \\
\hline & Control & 23 & 18.96 & 2.44 & & \\
\hline \multirow[t]{2}{*}{ Desire to learn English } & Experimental & 25 & 40.32 & 8.91 & -.25 & .80 \\
\hline & Control & 23 & 40.91 & 7.38 & & \\
\hline \multirow[t]{2}{*}{ Instrumental orientation } & Experimental & 25 & 17.92 & 3.96 & .23 & .82 \\
\hline & Control & 23 & 17.70 & 2.65 & & \\
\hline
\end{tabular}

TABLE IV: ANCOVA TESTS OF ATTITUdE AND MOTIVATION SCORES BETwEEN Two GRoups

\begin{tabular}{|c|c|c|c|c|c|c|}
\hline \multirow{2}{*}{ Variables } & \multirow{2}{*}{ Groups } & \multicolumn{2}{|c|}{ Pre-tests } & \multicolumn{2}{|c|}{ Post-tests } & \multirow{2}{*}{$F$} \\
\hline & & $M$ & $S D$ & $M$ & $S D$ & \\
\hline \multirow[t]{2}{*}{ Interest in English } & Experimental & 40.68 & 7.98 & 46.56 & 3.40 & $11.98 * *$ \\
\hline & Control & 41.43 & 6.27 & 41.61 & 7.21 & \\
\hline \multirow[t]{2}{*}{ Motivational Intensity } & Experimental & 37.64 & 5.44 & 46.00 & 3.48 & $43.56 * * *$ \\
\hline & Control & 38.61 & 5.10 & 38.48 & 4.55 & \\
\hline \multirow{2}{*}{$\begin{array}{l}\text { Attitudes toward English } \\
\text { learning }\end{array}$} & Experimental & 37.96 & 9.53 & 46.28 & 4.24 & $26.60 * * *$ \\
\hline & Control & 38.87 & 6.53 & 38.17 & 6.99 & \\
\hline \multirow{2}{*}{$\begin{array}{l}\text { Attitudes toward English } \\
\text { speaking people }\end{array}$} & Experimental & 32.00 & 6.83 & 37.00 & 3.44 & $10.84 *$ \\
\hline & Control & 33.22 & 5.35 & 32.39 & 6.37 & \\
\hline \multirow[t]{2}{*}{ Integrative orientation } & Experimental & 18.72 & 3.82 & 17.96 & 3.37 & .76 \\
\hline & Control & 18.96 & 2.44 & 18.74 & 2.75 & \\
\hline \multirow[t]{2}{*}{ Desire to learn English } & Experimental & 40.32 & 8.91 & 45.72 & 5.06 & $4.84 *$ \\
\hline & Control & 40.91 & 7.38 & 41.78 & 8.85 & \\
\hline \multirow[t]{2}{*}{ Instrumental orientation } & Experimental & 17.92 & 3.96 & 19.00 & 1.92 & $11.27 *$ \\
\hline & Control & 17.70 & 2.65 & 17.00 & 2.20 & \\
\hline
\end{tabular}

${ }^{*} p<.05, * * p<01, * * * p<001$

Therefore, flipped learning applying the jigsaw strategy had the positive effects on the increase of interest in English, motivational intensity, attitudes toward English, attitudes toward English speaking people, desire to learn English, and instrumental orientation of pre-serviced kindergarten teachers.

\section{DISCUSSION}

This research examined whether flipped learning applying jigsaw strategy is effective in English attitude and motivation of pre-serviced kindergarten teachers in EFL online classrooms. For this purpose, the Zoom online classes were opened for 10 weeks to run the lectures, and various discussion activities were presented for the experimental group and control group. In particular, the discussion and debate activities were differentiated from the control group by applying the jigsaw strategy to the experimental group only. The discussions of these results are as follows.

First, applying the jigsaw strategies in the flipped learning classes can promote the learners' participations, and make the complementary measures about doing nothing by certain group members, which has been raised as a disadvantage of group activities [8].

In fact, in this research, learners shared feedbacks with each other through online, and the worksheets they created were continuously exchanged through LMS or Zoom application. Activities designed to be shared by instructors and learners increased opportunities for experiencing different levels of English proficiency and allowed them to interact with less tension. Given the previous study [9] that learners in Eastern cultures, including South Korea, are passive in educating and evaluating their peers' learning activities, it can be seen as if the jigsaw strategies were appropriately used. It is necessary to design a class so that learners' prior experiences of flipped learning can be presented step by step and applied. In particular, it is necessary to systematically plan what learner's activities can increase participation in flipped learning.

Second, in the EFL contexts, the English attitude and motivation of pre-serviced kindergarten teachers were effective when applying the flipped learning method applying the jigsaw strategies. This can be supported by previous studies [6], [10] that learners studying languages in flipped learning classes can be more motivated and interact. 
Generally, EFL learners tend to be shy, passive, and afraid to speak [11], inhibited [12], and reluctant to participate with English [13] in the traditional classroom settings. They lack the ability to speak through spontaneous interactions, and at the same time, their anxiety about English increases, and they also show a sense of resistance to the use of English.

On the other hand, in the flipped learning class applying jigsaw strategies, they may motivate to be self-conscious and study in more comfortable environments. In other words, anxiety about English is relatively lowered, so attitudes and motivations toward English can also increase [14]. In addition, they can achieve the interactions through their cooperative learnings with peers who are similar to themselves [15], which in turn supports the learner's involvement in collaboration, authentic tasks, reflection, and dialog [16], [17].

Thus, in this study, it seems that online learners share feedback with each other, and the worksheets they create have increased attitudes and motivations for English whenever they are given the opportunity to continue sharing by professors and learners via LMS or Zoom application. Furthermore, the interactions between professors and learners in the classrooms could be increased, giving learners the opportunity to correct the misconceptions [18]. This allows learners to observe the learning process more closely and enhance their insight into learning [19].

Therefore, EFL language learning based on small group activities such as the jigsaw strategies is effective for the quantity of language use, enhancing the quality of the language use, and motivating language learning.

Third, in order to make online-based flipped learning more effective, not only diversification of discussion methods, but also overall thinking abut instructional design strategies and models are required.

In fact, the learners who participated in this study had difficulty in self-directed learning because they were accustomed to the direct teaching methods that only receives knowledge according to the traditional lecture forms. For this, learners' clear understanding of flipped learning should precede, and openness to contents that can be used in online classrooms should be improved. In particular, some materials on internet that are intended to be used in class are often not fully disclosed to learners, so the open shared information on internet for them should be prepared. This will be helpful for learners's self-directed learning.

\section{CONCLUSION}

This research is summarized as follows. This study applied the jigsaw strategies in flipped learning to improve English attitude and motivation of EFL pre-serviced kindergarten teachers. This study has devised a plan to improve learners' ability to use English in the nowadays situations where the proportions of distance classes increase due to the COVID-19 pandemic. It can also show the teaching methods that increase the English attitude and motivation of learners in the EFL contexts.

On the other hand, in the future research, it is necessary to be able to prepare a teaching and learning plan that can improve not only learners but also teachers' capabilities, and development of educational contents that can lead the flipped learning with online classrooms.

\section{CONFLICT OF INTEREST}

The authors declare no conflict of interest.

\section{AUTHOR CONTRIBUTIONS}

Hyelin Jeong conducted the research, analyzed the data, and wrote the paper; the author had approved the final version.

\section{REFERENCES}

[1] C. H. Crouch and E. Mazur, "Peer instruction: Ten years of experience and results," American Journal of Physics, vol. 69, no. 9, pp. 970-977, Sep 2001.

[2] T. Anderson, L. Rourke, D. R. Garrison, and W. Archer, "Assessing teaching presence in a computer conferencing context," Journal of Asynchronous Learning Networks, vol. 5, no. 2, pp. 2-17, March 2019.

[3] C. J. Brame, Flipping the Classroom, Nashville, TN: Academic Press, 2019, ch.9, pp.121-132.

[4] H. J. Han, C. I. Im, S. I. Han, and J. W. Park, "Instructional strategies for integrating online and offline modes of flipped learning in higher education," Journal of Education Technology, vol. 31, no. 1, pp. 1-38, Mar 2015.

[5] G. J. Hwang, M. A. Chen, H. Y. Sung, and M. H. Lin, "Effects of integrating a concept mapping-based summarization strategy into flipped learning on students' reading performances and perceptions in Chinese courses," British Journal of Educational Technology, vol. 50, no. 5, pp. 2703-2719, Sep 2019.

[6] W. Wu, J. Hsieh, and J. Yang, "Creating an online learning community in a flipped classroom to enhance EFL learners' oral proficiency," Educational Technology \& Society, vol. 20, no. 2, pp. 142-157, April 2017.

[7] R. C. Gardner and P. C. Smythe, "On the development of the attitude/motivation test battery," Canadian Modern Language Review, vol. 37, pp. 510-525, March 1981.

[8] H. Ning, "Adapting cooperative learning in tertiary ELT," ELT Journal, vol. 65, no.1, pp. 60-70, Jan 2011.

[9] Y. E. Oh and H. Lee, "Exploring the effect of face-to-face and anonymous feedback on L2 writing revision," English21, vol. 28, no. 1, pp. 219-243, Mar 2015.

[10] C. J. Lin and G. J. Hwang, "A learning analytics approach to investigating factors affecting EFL students' oral performance in a flipped classroom," Educational Technology \& Society, vol. 21, no. 2, pp. 205-219, Jan. 2018.

[11] M. Hata, "Literature review: Using computer-mediated communication in second language classrooms," Osaka Keidai Ronshu, vol. 54, no. 3, pp. 115-125, Sep. 2003.

[12] P. Wallace, The Psychology of the Internet, New York, NY: Cambridge University Press. 1999.

[13] J. Roed, "Language learner behavior in a virtual environment," Computer Assisted Language Learning, vol. 16, no. (2-3), pp. 155-172, Jul. 2003.

[14] A. AbuSeileek, "Cooperative vs. individual learning of oral skills in a CALL environment," Computer Assisted Language Learning, vol. 5, no. 20, pp. 493-514, Dec. 2007.

[15] M. Cooper and C. Selfe, "Computer conferences and learning: authority, resistance, and internally persuasive discourse," College English, vol. 52, no. 8, pp. 847-873, Dec. 1990.

[16] M. Liaw, "E-learning and the development of intercultural competence," Language Learning \& Technology, vol. 10, no. 3, pp. 49-64, Sep. 2006.

[17] R. Oliver and C. McLoughlin, "Using networking tools to support online learning," Innovation in Open and Distance Learning, 1st ed, F. Lockwood, and A. Gooley, Eds. London: Routledge, 2001, pp. 148-159.

[18] S. Turkle, Life on the Screen: Identity in the Age of the Internet, New York, NY: Simon \& Schuster, 1997.

[19] A. Roehl, S. L. Reddy, and G. J. Shannon, "The flipped classroom: An opportunity to engage millennial students through active learning," Journal of Family and Consumer Sciences, vol. 105, no. 2, pp. 44-49, Aug. 2013. 
Copyright $\odot 2021$ by the authors. This is an open access article distributed under the Creative Commons Attribution License which permits unrestricted use, distribution, and reproduction in any medium, provided the original work is properly cited ( $\underline{\text { CC BY 4.0) }}$.

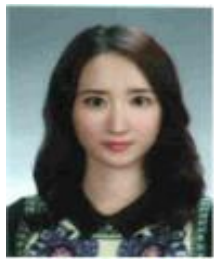

Hyelin Jeong was born in South Korea in 1985. She obtained her Ph.D for Seoul National University, South Korea in 2017. She worked as part time instructor at Seoul National University of Education, Duksung Woman's University, and Sangmyung University. She currently works as assistant professor department of global child education at Woosong University, South Korea. She is concerned and studied about the transition from early childhood to childhood education, computer-based education context, education environment in early childhood. 